INTERNATIONAL HIGHER EDUCATION - NUMBER 64 SUMMER 2011 Pages 6-7.

Internationalization of Higher Education: Nine Misconceptions

Hans de Wit

Hans de Wit is professor of internationalization at the School of Economics and Management, Hogeschool van Amsterdam, University of Applied Sciences, Netherlands. This is an abridged version of his public lecture in Amsterdam, April 6, 2011. E-mail: j.w.m.de.wit@hva.nl .

Internationalization in European higher education has developed over the last 20 years, from a marginal point of interest to a central factor-also called a mainstreaming of internationalization. Indisputably, globalization of our societies and economies has expanded the influence of competition and market processes on the manner in which internationalization is implemented. Internationalization distinguishes many motives and approaches. The mainstreaming of internationalization assumes a more integral process-based approach, aimed at a better quality of higher education and competencies of staff and students. Reality is less promising, however, although the international dimension takes an increasingly central role in higher education. Still, there is a predominantly activity-oriented or even instrumental approach toward internationalization, which leads to major misconceptions about the nature of this development. Nine misconceptions will be described (two of them coinciding with a myth as described in IHE by Jane Knight in "Five Myths About Internationalization," no. 62, winter 2011), whereby internationalization is regarded as synonymous with a specific programmatic or organizational strategy to promote internationalizationin other words, where the means appear to have become the goal. 


\section{EDUCATION IN THE ENGLISH LANGUAGE}

The influence of the English language as a medium of communication in research has been dominant for a long period of time. Also, over the past 20 years the tendency in higher education has been to teach in English, as an alternative for teaching in one's mother tongue. There are several unintended negative effects. Increasingly, education offered in the English language is regarded as the equivalent of internationalization, which results in a decreasing focus on other foreign languages; in an insufficient focus on the quality of the English spoken by students and teachers for whom English is not their native language; and thus leading to a decline in the quality of education.

\section{STUDYING OR STAYING ABROAD}

A study or internship abroad as part of your home studies is often regarded as the equivalent of internationalization. In particular, the European Commission's policy to stimulate this manner of mobility has contributed to that instrumental approach over the last 25 years. It is questionable, however, whether the imbalanced and oversimplified approach to mobility matches internationalization. As well, it can be said that mobility is merely an instrument for promoting internationalization and not a goal in itself. Mobility needs to be finely embedded in the internationalization of education. It should be determined whether these Internationalization in European higher education has developed over the last 20 years, from a marginal point of interest to a central factor-also called a mainstreaming of internationalization. Indisputably, globalization of our societies and economies has expanded the influence of competition and market processes 
on the manner in which internationalization is implemented. Internationalization distinguishes many motives and approaches. The mainstreaming of internationalization assumes a more integral process-based approach, aimed at a better quality of higher education and competencies of staff and students. Reality is less promising, however, although the international dimension takes an increasingly central role in higher education. Still, there is a predominantly activity-oriented or even instrumental approach toward internationalization, which leads to major misconceptions about the nature of this development. Nine misconceptions will be described (two of them coinciding with a myth as described in IHE by Jane Knight in "Five Myths About Internationalization," no. 62, winter 2011), whereby internationalization is regarded as synonymous with a specific programmatic or organizational strategy to promote internationalizationin other words, where the means appear to have become the goal.

added values are developed among students; and more innovative reflection is required on alternative ways of achieving these added values, for instance by the use of distance education and virtual mobility.

\section{AN INTERNATIONAL SUBJeCT}

A third misconception that continues to surface persistently is that internationalization is synonymous with providing training based on international content or connotation: European studies, international business, or universal music. Within the institutions and schools offering these programs, the prevailing opinion seems to imply that, in this way, internationalization has been properly implemented. Without meaning to ignore the valuable contribution of such 
programs, again, it is too simplistic and instrumental an argument to declare regional studies as synonymous with internationalization.

\section{HAVING Many INTERnational StUdents}

A fourth misconception of internationalization is the assumption that having many international students equals that trend. Without denying that the combination of local and international students in the lecture room can make a significant contribution to internationalization, simply having international students is not sufficient. Unfortunately, countless examples can be given of programs that are oriented exclusively toward international students or where international students are being added as an isolated group.

\section{FEW INTERNATIONAL STUDENTS GUARANTEES SuCCESS}

The other side of the preceding misconception occurs as well. In particular, many international programs have developed a distorted proportion between the number of local and international students. Partly as a result of the increasing national and international competition for international students, the proportion between local and international students becomes more and more unequal. Thus, one can hardly speak of an international classroom setting. Conversely, this development has a negative effect on the internationalization of mainstream, nonEnglish-language programs. Local students with a certain, whether or not motivated, international interest preferably enroll in the international programswhich means the interest of mainstream education in the local language dwindles. Also, in these programs, the presence of a small number of international students creates tensions. Should the courses be taught in English if there are only one or 
two international students in the lecture room? How can the integration of international students be realized in such distorted proportions?

\section{No NeEd to Test INTERCUltural AND INTERNATIONAL COMPETENCIES}

A sixth misconception assumes that students normally acquire intercultural and international competencies if they study or serve their internship abroad or take part in an international class. This misconception is closely related to the previous ones about mobility, education in English, and the presence of international students. If these kinds of activities and instruments are considered synonymous with internationalization, then it is obvious to assume that intercultural and international competences will therefore also be acquired. Once again, reality is more complicated. It is not guaranteed from the outset that these activities will actually lead to that result. After all, students can completely seclude themselves from sharing experiences with other students and other sections of the population in the countries they visit.

\section{The More PARTNerships, THE MORe InTERnationaL}

A seventh misconception on internationalization is the focus on partnerships: the more partnerships, the more success of internationalization. Globalization, competition, and market processes have reinforced the development toward strategic partnerships. This tendency toward strategic partnerships often implicates intentions, however. The majority of partnerships remain bilateral, and in several institutions and schools the number far exceeds the number of students and teachers being exchanged. 


\section{Higher EDUCATION-INTERNATIONAL by NATURE}

At universities and among their researchers, the general opinion identified a truly international characteristic, and thus there is no need to stimulate and guide internationalization. Thereby, references are made to the Renaissance, the time of the philosopher Erasmus (ca. 1467-1536), whom the European exchange program is named after. This historic reference ignores the fact that universities, mostly originated in the 18th and 19th century, had a clear national orientation and function. Internationalization does not arrive naturally in general universities and universities of applied sciences, but needs to be introduced. That is why the rather widely accepted definition of internationalization by Jane Knight refers to an integration process.

\section{Internationalization As a Precise GoAl}

Most of the mentioned misconceptions conceive an activity or instrument as synonymous with internationalization. The last, also fairly prevailing, misconception regards internationalization as a main goal, and therefore it is in line with the misconceptions mentioned earlier. Internationalization is a process to introduce intercultural, international, and global dimensions in higher education; to improve the goals, functions, and delivery of higher education; and thus to upgrade the quality of education and research. If internationalization is regarded as a specific goal, then it remains ad hoc and marginal.

To comprehend the challenges and opportunities for the internationalization of higher education it is compelling to recognize that these misconceptions are still fairly common. 